\title{
接着接合板の端部特異応力場の強さと微小界面縁き裂の応力拡大係数との関係
}

\author{
小田 和広*1，高畑 洋介*2，野田 尚昭*3，堤 紀子*1
}

\section{Relation between intensity of singular stress at interface edge and stress intensity factor of small edge interface crack in butt joint}

\author{
Kazuhiro ODA ${ }^{* 1}$, Yosuke TAKAHATA ${ }^{* 2}$, Nao-Aki NODA*3 and Noriko TSUTSUMI ${ }^{* 1}$ \\ ${ }^{* 1}$ Department of Mechanical and Energy Systems Engineering, Oita University \\ 700 Dannoharu, Oita-shi, Oita 870-1192, Japan \\ ${ }^{* 2}$ Graduate school of Engineering, Oita University \\ 700 Dannoharu, Oita-shi, Oita 870-1192, Japan \\ ${ }^{* 3}$ Department of Mechanical Engineering, Kyushu Institute of Technology \\ 1-1 Sensui-cho, Tobata-ku, Kitakyushu-shi, Fukuoka 804-8550, Japan
}

\section{Received 10 October 2015}

\begin{abstract}
This paper deals with the effect of adhesion layer and material combination on the stress intensity factor for small edge interface crack in butt joint plate under uniaxial tension. The stress intensity factors of the small edge interface crack are analyzed by the crack tip stress method with varying the crack length, adhesive thickness and material combination. The stress intensity factor of the edge interface crack is controlled by the singular stress field at the interface free edge in butt joint without the crack when the crack is very small. The calculation shows that the stress intensity factors $K_{1}$ and $K_{2}$ of the small edge interface crack are related to the intensity of singular stress field $K_{\sigma}$ and the singularity index $\lambda_{12}$ at the interface edge without the crack. Then, it is found that the stress intensity factors can be expressed as $K_{1}+i K_{2}=\left(F_{1}+i F_{2}\right) K_{\sigma} a^{\lambda_{12}-0.5} \sqrt{\pi}(1+2 i \varepsilon)$ and the normalized stress intensity factors $F_{1}$ and $F_{2}$ are constant values when the crack length $a / h<10^{-2}$ irrespective of the adhesive thickness and length of butt joint plate. Therefore, it can be concluded that $K_{l}$ and $K_{\sigma}$ are an equivalent parameter each other.
\end{abstract}

Key words : Interface crack, Stress intensity factor, Intensity of singular stress, Fracture mechnaics, Bonded plate

\section{1. 緒言}

接着接合法は，非金属同士の接合や微小部材の接合が可能であり，面接合であるので密閉性にも優れており， 多くの産業で使用されている．異種材料を接合した接合材料の界面端では応力特異性が生じるため，界面端から 剥離 (界面き裂) が生じ，破壞にいたる場合が多い，そのため，接着接合材の接合角部の特異応力場については， これまで多くの理論的あるいは解析的研究が行われている（Bogy, 1965 ; 陳，西谷，1991，1993；張他，2011a,b). 接着・接合強度は，材料組合せや接着層厚さに依存し，一般に接着層が薄くなるほど強度は増加する（Suzuki, 1987 ; Akisanya and Meng, 2003 ; Afendi et al., 2013). 著者らの一人は, 実際の接合板の引張試験結果の整理に接合 端部特異場の強さ $K_{\sigma}$ を適用し, 種々の接着層厚さの接着強度が $K_{\sigma}=$ 一定で表されることを示した (野田他, 2014). 一方，接着構造の特異応力場に注目して強度評価を行う場合，同じ材料組合せの接合板でも接合形状によって特 異性指数が変化するという不都合を解決するため, 界面端部に微小なき裂を想定し，そのき裂の応力拡大係数に より統一的に強度評価を実施する試みも検討されている（井岡他, 2002 ; 野田他, 2014 ; Noda et al., 2015). 最近, 野田らは, 仮想的な微小界面き裂による応力拡大係数を利用した接着接合材の強度評価の有効性を示している(野 田他, 2014 ; Noda et al., 2015)。異種材料接合材の強度評価の例として, 図 1 のような接着接合試験片の各接着層

No.15-00557 [DOI:10.1299/transjsme.15-00557], J-STAGE Advance Publication date : 17 June, 2016

${ }^{* 1}$ 正員，大分大学工学部（干870-1192 大分県大分市旦野原 700)

*2 大分大学大学院工学研究科

*3 正員, フェロー, 九州工業大学大学院工学研究院（†804-8550 福岡県北九州市戸畑区仙水町 1-1）

E-mail of corresponding author: oda-kazuhiro@oita-u.ac.jp 
Table 1 Material properties of the butt joint specimen (Fig. 1).

\begin{tabular}{lc|cc}
\hline \multicolumn{2}{c|}{ Material } & $E[\mathrm{GPa}]$ & $v$ \\
\hline Material 1 & YH75 (AL-alloy) & 71 & 0.33 \\
\hline Material 2 & Epoxy adhesive & 3.4 & 0.396 \\
\hline Material 3 & SUS304 & 206 & 0.3 \\
\hline
\end{tabular}
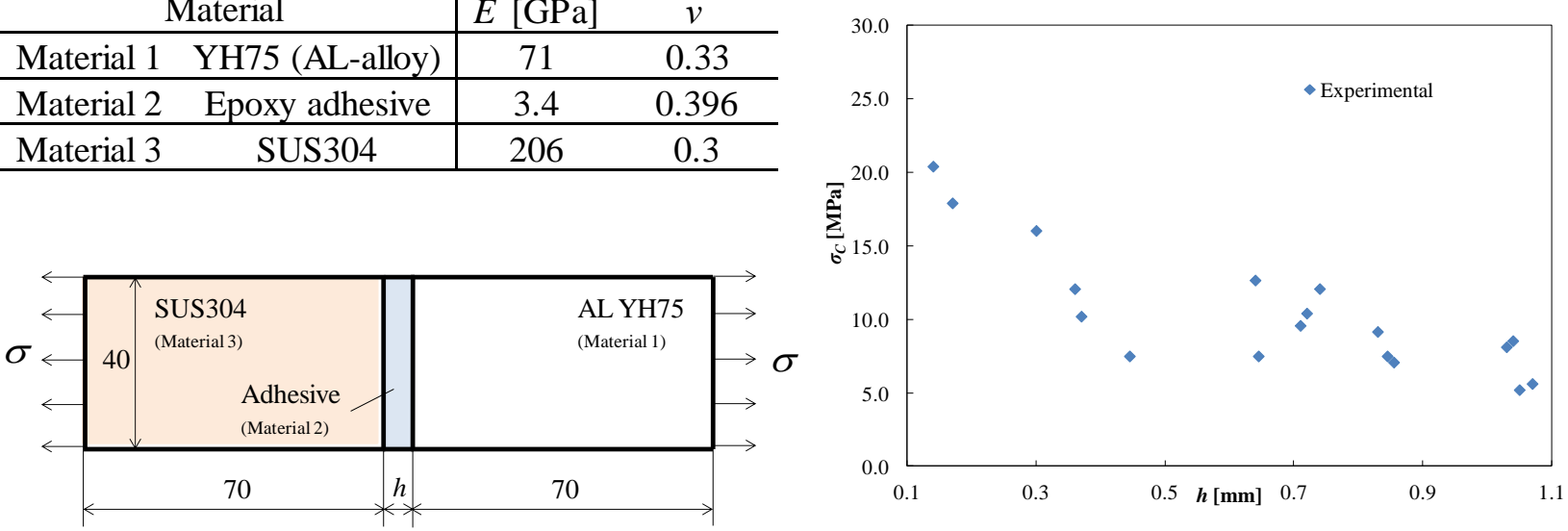

Fig.1 Butt joint specimen used for tensile test.

Fig.2 Failure stress $\sigma_{\mathrm{c}}$ for various thickness $h$ (Afendi et al., 2013)

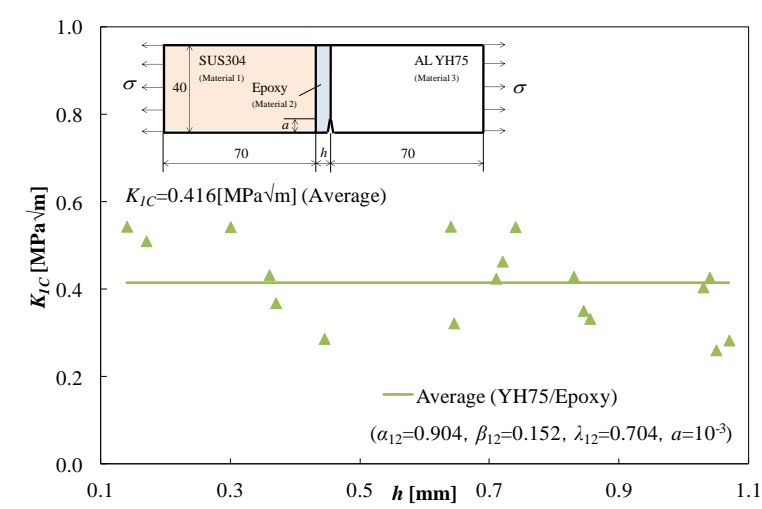

(a) $K_{l C}$ vs. $h$

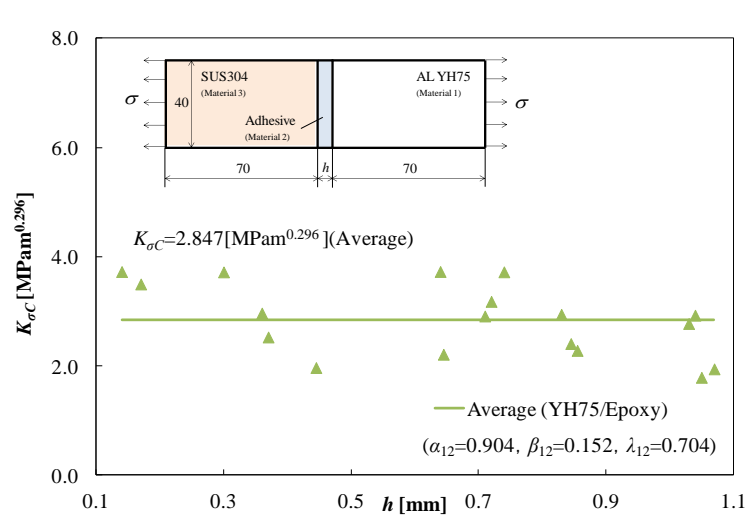

(b) $K_{\sigma C}$ vs. $h$

Fig.3 Adhesive strength of butt joint specimen expressed as a constant critical values of $K_{l C}$ and $K_{\sigma C}$ for various adhesive thickness $h$.

(a) Values of $K_{l C}$ for fictitious interface crack between YH75 and epoxy adhesive are calculated by the crack tip stress method when the crack length is assumed $a=10^{-3}[\mathrm{~mm}]\left(10^{-3}<a / h<10^{-2}\right)$, (b) values of $K_{\sigma C}$ of YH75/epoxy interface corner edge are evaluated by the finite element method.

厚さ $h$ に対する引張破断強度 $\sigma_{C}$ の実験結果を図 2 に示す (Afendi et al., 2013). 表 1 に接合試験片の材料定数を示 寸. 図 2 の破断強度 $\sigma_{C}$ を用い, 界面に仮想的なき裂を想定し各接着層厚さ $h$ に対して求めた限界の応力拡大係 数 $K_{1 C}$ で整理した結果が図 3(a), き裂の無い接合板の端部特異応力場の強さ $K_{\sigma C}$ で破断限界を示した結果が図 3(b)である. 図3(a)の $K_{1 C}$ は，アルミ合金とエポキシの界面に長さ $a=10^{-3}[\mathrm{~mm}]\left(a / h=10^{-3} \sim 10^{-2}\right)$ の微小なき裂を仮 定し解析した応力拡大係数であり，図3(b)の $K_{\sigma C}$ は，アルミ合金とエポキシの界面端部における特異応力場の強 さである. 実験值のばらつきはあるものの両パラメータで整理した結果は, 接着層厚さにかかわらず破壊基準 $K_{1 C}$ =一定あるいは $K_{\sigma C}=$ 一定とみな寸ことができ， $K_{1 C}$ あるいは $K_{\sigma C}$ に基づく破壊力学的評価はどちらも同様な結 果を与えると考えられる.

著者らのこれまでの研究により，接合材の界面端部の微小な界面き裂の応力拡大係数は，き裂の無い端部特異 場の強さに強く影響されることが明らかになっている (小田他, 2015). しかしながら, 破壊力学的手法に基づく 突合せ継手の界面強度評価に対する二つのアプローチである $K_{l}$ と $K_{\sigma}$ のパラメータ間にどのような関係があるか については明確にされていない，そこで本研究では，図 4(a)に示すような上下が異なる材料の接着接合板の接合 界面 12 上の界面縁き裂問題の応力拡大係数について検討寸る. 任意の材料組合せに対して解析を行い, 材料 3 (上 部被接着材）の違いが界面縁き裂の応力拡大係数にどのような影響を与えるかに注目し，図 4(b)のようなき裂が ない場合の界面端部特異応力場との関係を明らかにする. 


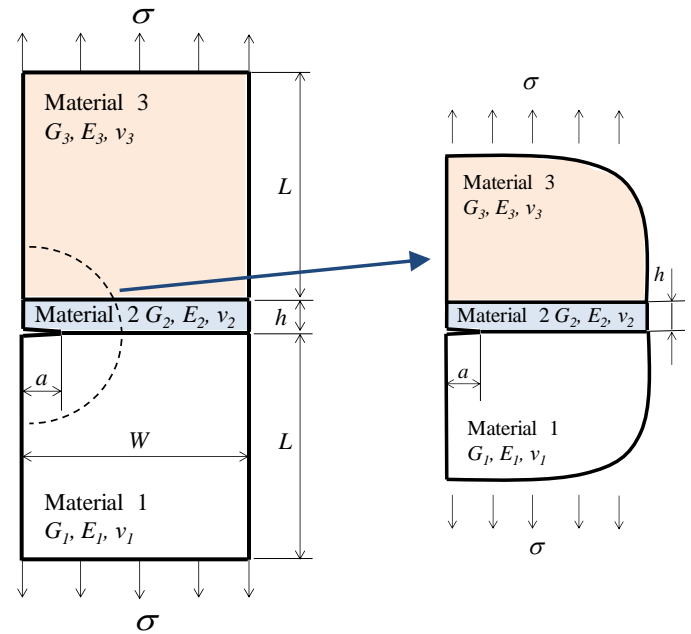

(a) with a small interface edge crack

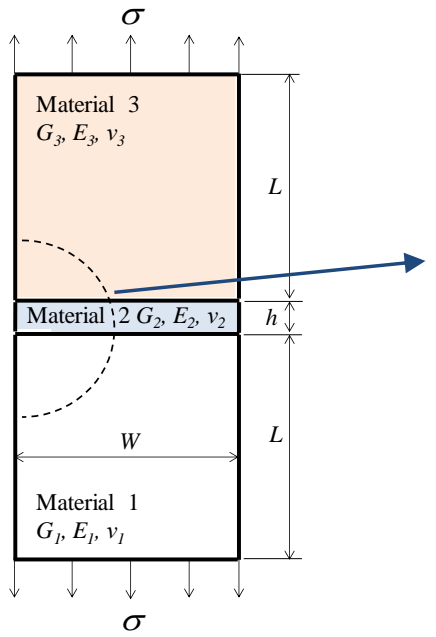

(b) without a crack

Fig.4 Butt joint subjected to tension.

\section{2. 解析方法}

図 4(a)のような微小界面縁き裂を有する異種材料接合板に引張応力が作用する未知問題について考える．材料 $1 ， 2 ， 3$ はそれぞれ等方弾性体とし, 横弾性係数 $G_{i}$, ヤング率 $E_{i}$, ポアソン比 $v_{i}(i=1,2,3)$ である. 下添字は 材料 $1 ， 2 ， 3$ を表す. 解析モデルは, き裂長さ $a$, 板幅 $W$, 板の長さ $L(L=W)$, 接着層厚さ $h$ とする.

本研究では, 有限要素法によって得られるき裂先端節点の応力值をそのまま利用し, 図 4(a)に示寸応力拡大係 数が未知の問題と図 5 に示寸基準問題のき裂先端節点の応力值との比をとることにより応力拡大係数を決定する, 第ゼ口節点法を用いた (小田他，2009；野田他，2010；小田，野田，2012).

この解析法では, 応力拡大係数が既知である基準問題の負荷応力 $T$ と $S$ を調節することによって, 未知の問 題と等しい特異応力場を作り出す，界面き裂先端は混合モード状態となるため，基準問題として，図 5 に示す一 様な引張応力 $T$ およびせん断応力 $S$ を受ける接合無限板を考える. 引張応力 $T=1$ あるいはせん断応力 $S=1$ と した場合の基準問題の界面き裂先端節点の FEM 解析值をそれぞれ $\sigma_{y 0, F E M}^{T=1} *, \tau_{x y 0, F E M}^{T=1}$ *および $\sigma_{y 0, F E M}^{S=1}$ *, $\tau_{x y 0, F E M}^{S=1}$ *とし，応力拡大係数が未知の問題（図 5)のそれを $\sigma_{y 0, F E M}, \tau_{x y 0, F E M}$ と表記すれば，基準問題と未知問 題のき裂先端節点応力が等しいという条件より, 基準問題に作用させる負荷応力 $T, S$ の值は次式より決定で きる.

$$
T=\frac{\sigma_{y 0, F E M} \cdot \tau_{x y, F E M}^{S=1} *-\sigma_{y 0, F E M}^{S=1} * \cdot \tau_{x y 0, F E M}}{\sigma_{y 0, F E M}^{T=1} * \tau_{x y 0, F E M}^{S=1} *-\sigma_{y 0, F E M}^{S=1} * \tau_{x y 0, F E M}^{T=1} *}, \quad S=\frac{\sigma_{y 0, F E M}^{T=1} * \tau_{x y 0, F E M}-\sigma_{y 0, F E M} \cdot \tau_{x y 0, F E M}^{T=1} *}{\sigma_{y 0, F E M}^{T=1} * \tau_{x y 0, F E M}^{S=1} *-\sigma_{y 0, F E M}^{S=1} * \cdot \tau_{x y 0, F E M}^{T=1} *}
$$

ここで, FEM 解析の際，二つの問題でき裂先端付近のメッシュパターンおよび材料定数が等しいという条件が 必要である(小田他, 2009).

式(1)より求めた $T, S$ の值より, 基準問題である異材接合無限板中の界面き裂の応力拡大係数は, 次式より 求められる.

$$
K_{1}^{*}+i K_{2}^{*}=(T+i S) \sqrt{\pi a^{*}}(1+2 i \varepsilon), \quad \varepsilon=\frac{1}{2 \pi} \ln \left[\left(\frac{\kappa_{1}}{G_{1}}+\frac{1}{G_{2}}\right) /\left(\frac{\kappa_{2}}{G_{2}}+\frac{1}{G_{1}}\right)\right]
$$

ここで， $\varepsilon$ は振動特異性指数， $\kappa_{i}=3-4 v_{i}$ (平面ひずみ),$\left(3-v_{i}\right) /\left(1+v_{i}\right)$ (平面応力),$v_{i}$ はポアソン比 $(i=1,2)$ である. 式(2)の応力拡大係数は未知の問題のものと等しいため, 図4(a)の未知問題の応力拡大係数は,

$$
K_{1}=K_{1}^{*}, \quad K_{2}=K_{2}^{*}
$$

である. 以上より，未知の問題の応力拡大係数 $K_{1}$ と $K_{2}$ を簡便に計算することができる. ここで得られる応力拡 
大係数は，次のように基準問題の界面き裂長さ $2 a^{*}$ を基準長さとしたものであることに注意する.

$$
\sigma_{y}+i \tau_{x y}=\frac{K_{1}+i K_{2}}{\sqrt{2 \pi r}}\left(\frac{r}{2 a^{*}}\right)^{i \varepsilon}
$$

ここで, 基淮問題の応力拡大係数およびき裂長さ半長には*を付けて表記している.

解析には有限要素法解析プログラム MSC.Marc を用い，8 節点四角形要素を使用した．要素分割はき裂先端で の要素サイズ $e$ がき裂長さ $a$ に対して $e / a=1 / 729$ となるように設定し, 図 5 のような規則的なパターンを用いた. き裂長さと板幅の比 $a / W$, 接着層厚さと板幅の比 $h / W$ を変化させ，材料 1,3 (被接着材） と材料 2 (接着材) の材料組合せは，式(5)の Dundurs の複合パラメータによって表すものとした．式(5)，(6)の下添字は材料 1，2，3 を表し， $\alpha_{i j}, \beta_{i j}$ は材料 $i$ と $j$ の組合せを示寸.

$$
\begin{gathered}
\alpha_{i j}=\frac{G_{i}\left(\kappa_{j}+1\right)-G_{j}\left(\kappa_{i}+1\right)}{G_{i}\left(\kappa_{j}+1\right)+G_{j}\left(\kappa_{i}+1\right)}, \beta_{i j}=\frac{G_{i}\left(\kappa_{j}-1\right)-G_{j}\left(\kappa_{i}-1\right)}{G_{i}\left(\kappa_{j}+1\right)+G_{j}\left(\kappa_{i}+1\right)} \\
G_{i}=\frac{E_{i}}{2\left(1+v_{i}\right)}, \quad \kappa_{i}= \begin{cases}\frac{3-v_{i}}{1+v_{i}} & \text { (plane stress) } \\
3-4 v_{i} & \text { (plane strain) }\end{cases}
\end{gathered}
$$

図 4(b)のき裂の無い接合板の特異場の強さの解析は，張らの手法を用いた（張他，2011a，2011b）.
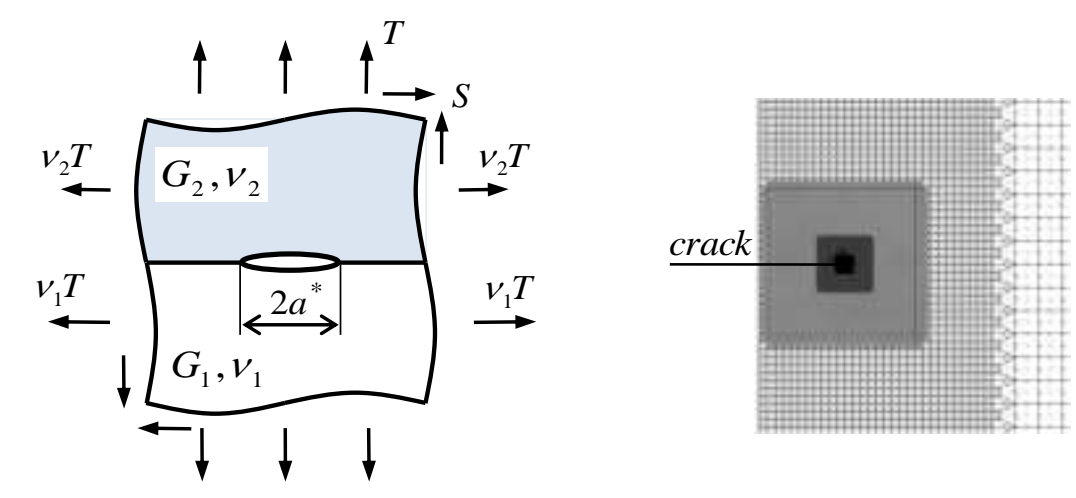

Fig. 5 Reference problem used in the crack tip stress method and FEM mesh pattern around the interface crack tip.

\section{3. 解析結果および考察}

著者らは，これまでに図 4(a)の被接着材（材料 1 と 3）が同じ場合の一軸引張りおよび面内曲げを受ける接着 接合材に対する解析を行い, き裂が無い場合の接合界面端部特異性を考慮することにより, 接着層界面端部に生 じた微小な界面き裂の応力拡大係数の評価式を示している（小田他，2015). 本研究では，図 4(a)に示寸上下が異 なる材料の接着接合板の接合界面 12 上の微小な界面縁き裂の応力拡大係数について, 同様の検討を行い, 応力拡 大係数の特性について検討および考察を行った.

\section{$3 \cdot 1$ 界面端部特異応力場に対する接着層厚さと材料組合せの影響}

微小な界面縁き裂は界面端部特異応力場の影響を強く受けるので，まず，図 4(b)のき裂の無い異材接合板につ いて解析を行い，接着層を有する異材接合材料の界面端部特異応力場について検討を行った.

基本となる図 6 のような 2 つ材料の接合板の接合端部特異応力場については，すでに理論的な解析がなされ ている (陳, 西谷, 1993). 本研究では接合界面上の特異応力分布に注目して図 6 のように $\theta=\pi / 2$ を代入して陳・ 西谷の式を整理することにより, 界面に沿う特異応力場を次のように表すことができる.

$$
\sigma_{y}(r)=\frac{K_{\sigma}}{r^{1-\lambda_{12}}}, \quad \tau_{x y}(r)=\frac{f_{r \theta}}{f_{\theta \theta}} \frac{K_{\sigma}}{r^{1-\lambda_{12}}}
$$




$$
\begin{aligned}
& f_{\theta \theta}=2 \lambda_{12}\left(\lambda_{12}+1\right) Y_{2} \sin \left(\lambda_{12} \pi / 2\right)+2 \lambda_{12}{ }^{2} Y_{1} \cos \left(\lambda_{12} \pi / 2\right), \\
& f_{r \theta}=2 \lambda_{12}\left(\lambda_{12}-1\right) Y_{1} \sin \left(\lambda_{12} \pi / 2\right)-2 \lambda_{12}{ }^{2} Y_{2} \cos \left(\lambda_{12} \pi / 2\right), \\
& Y_{1}=4 \lambda_{12} \beta_{12} \cos \left(\lambda_{12} \pi\right)+2 \beta_{12}\left[\cos \left(\lambda_{12} \pi\right)-1\right]+4 \lambda_{12}\left(\lambda_{12}+1\right)\left(\alpha_{12}-\beta_{12}\right), \\
& Y_{2}=2\left(2 \lambda_{12} \beta_{12}-1\right) \sin \left(\lambda_{12} \pi\right)
\end{aligned}
$$

ここで， $K_{\sigma}$ は接合界面端特異応力場の強さ， $f_{\theta \theta}, f_{r \theta}$ は材料 1 と材料 2 の組合せのみで決まる関数である. 材料 1 と材料 2 の界面端部特異性指数 $\lambda_{12}$ は, 式(9)の特性方程式から求められる（陳，西谷，1993）.

$$
\left[\sin ^{2}\left(\frac{\pi}{2} \lambda_{i j}\right)-\lambda_{i j}{ }^{2}\right]^{2} \beta_{i j}^{2}+2 \lambda_{i j}^{2}\left[\sin ^{2}\left(\frac{\pi}{2} \lambda_{i j}\right)-\lambda_{i j}{ }^{2}\right] \alpha_{i j} \beta_{i j}+\lambda_{i j}{ }^{2}\left(\lambda_{i j}{ }^{2}-1\right) \alpha_{i j}{ }^{2}+\frac{\sin ^{2}\left(\lambda_{i j} \pi\right)}{4}=0
$$

式(7), (8)より, 接合界面に生じる特異応力成分の比は $\sigma_{y}(r) / \tau_{x y}(r)=f_{\theta \theta} / f_{r \theta}$ で一定であり, 理論的に材料 1 と 2 の組合せのみで定まることがわかる.
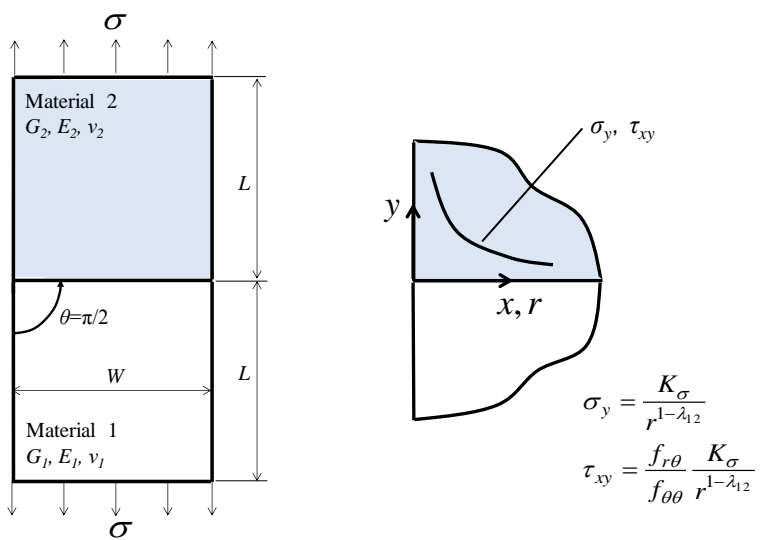

Fig. 6 Bi-material strip and singular stress distribution near the interface free edge.

上記の議論を踏まえて，図 4(b)の接着層を有する接合板の界面端特異場に対する接着層厚さおよび材料組合せ の影響を検討する. 界面端特異性の有無は $\alpha_{i j}\left(\alpha_{i j}-2 \beta_{i j}\right)>0$ の条件で決まるため, 以下に示卞解析例は, 界面 12 および界面 23 に対寸る特異性の有無を考慮して, 表 2 に示寸材料組合せを用いた. 表 3 には, 表 2 の各材料組合 せに対する Dundurs パラメータおよび特異性指数を示す.

Table 2 Material properties used in the present analyses.

\begin{tabular}{c|cc|cc|cc|cc}
\hline \multirow{2}{*}{ Group } & \multicolumn{2}{|c|}{ Material 1 } & \multicolumn{2}{c|}{ Material 2 } & \multicolumn{2}{c|}{ Material 3 } & \multicolumn{2}{c}{ Edge singularity } \\
& (lower) & \multicolumn{2}{c|}{ (adhesion layer) } & \multicolumn{2}{c}{ (upper) } & & interface12 & interface23 \\
\hline 1 & 1000.0 & 0.002 & 176.471 & 0.118 & 70.3 & 0.345 & $\bigcirc$ & $\bigcirc$ \\
\hline 2 & 1000.0 & 0.002 & 176.471 & 0.118 & 238.3 & 0.35 & $\bigcirc$ & $\times$ \\
\hline 3 & 1000.0 & 0.409 & 333.333 & 0.003 & 15.34 & 0.15 & $\times$ & $\bigcirc$ \\
\hline 4 & 1000.0 & 0.409 & 333.333 & 0.003 & 466 & 0.26 & $\times$ & $\times$ \\
\hline
\end{tabular}

Table 3 Dundurs' parameters and the singularity index for material combination shown in Table 2.

\begin{tabular}{c|c|c|c|c|c|c}
\hline Group & $\alpha_{12}$ & $\beta_{12}$ & $\alpha_{23}$ & $\beta_{23}$ & $1-\lambda_{12}$ & $1-\lambda_{23}$ \\
\hline 1 & 0.7 & 0.3 & -0.43 & -0.109 & 0.0652 & 0.0679 \\
\hline 2 & 0.7 & 0.3 & 0.149 & 0.115 & 0.0652 & -0.0102 \\
\hline 3 & 0.5 & 0.3 & 0.912 & -0.384 & -0.0558 & 0.1317 \\
\hline 4 & 0.5 & 0.3 & 0.167 & 0.134 & -0.0558 & -0.0151 \\
\hline
\end{tabular}


図 7 に接着層厚さ $h / W=0.002 ， 0.01 ， 1$ の場合で求めた接合界面 12 上の応力分布 $\sigma_{y}(r)$ を示す．ここで， $r$ は界 面端からの距離, $\sigma_{y}(r)$ は接合界面上の $y$ 方向垂直応力である. Group 2 と 4 の $h / W$ を変化させた結果は Group 1 と 3 と同様の結果であるため, $h / W=0.002$ の応力分布のみ示した. 図 7 の両対数グラフの結果より, 接合端部近 傍では，応力の大きさは接着層厚さや材料 3 （上部被接着材）に影響を受けるが，応力分布の傾きはそれぞれ一 定で，材料 1 （下部被接着材）と材料 2 （接着材）の組合せのみによって決まることがわかる．また，その傾きは 式(9)の特性方程式から求めた応力特異性指数 $\lambda_{12}-1$ の值とよく一致する.

図 8(a)に $h / W=0.002$ の場合で解析した接合界面 12 上の接合界面端近傍の $\sigma_{y}(r)$ と $\tau_{x y}(r)$ の比と界面からの相 対距離 $r / h$ との関係を示す. 記号は解析より求めた $\sigma_{y}(r) / \tau_{x y}(r)$ の值であり, 破線は式(7), (8)より求めた $f_{\theta \theta} / f_{r \theta}$ の值である. 図 8(a)より，接合端部近傍では， $\sigma_{y}(r) / \tau_{x y}(r)$ の值は，材料 3 (上部被接着材）に影響されず一定 值であり, FEM 解析から求めた $\sigma_{y}(r) / \tau_{x y}(r)$ の值と式(7), (8)から求めた $f_{\theta \theta} / f_{r \theta}$ の值は一致していることがわか る. 図 8(b)に解析から求めた接合界面 12 上の接合界面端部の $\sigma_{y}(r)$ と $\tau_{x y}(r)$ の比と接着層厚さ $h / W$ との関係を 示寸. 応力 $\sigma_{y}(r), \tau_{x y}(r)$ の值は, 界面端部近傍の $r / W=10^{-7}$ 付近の值を用いた. 図 8(b)より, 材料 3 (上部被接着 材）に関係なく，接着層厚さを広範囲に変化させても $\sigma_{y} / \tau_{x y}$ の值は一定であることがわかる. したがって, 図 4(a)のような接着接合板の材料 1 (下部被接着材) と材料 2（接着材）の接合界面端特異応力は，応力特異性指数 $1-\lambda_{12}$ および応力成分の比 $\sigma_{y} / \tau_{x y}$ は一定值であり，材料 1 （下部被接着材）と 2 （接着材）の組合せのみによっ て式(7),(8) と同様に表すことができる. 寸なわち，接着層厚さおよび材料 3 の違いは，すべて $K_{\sigma}$ の值の変化とな って表される.

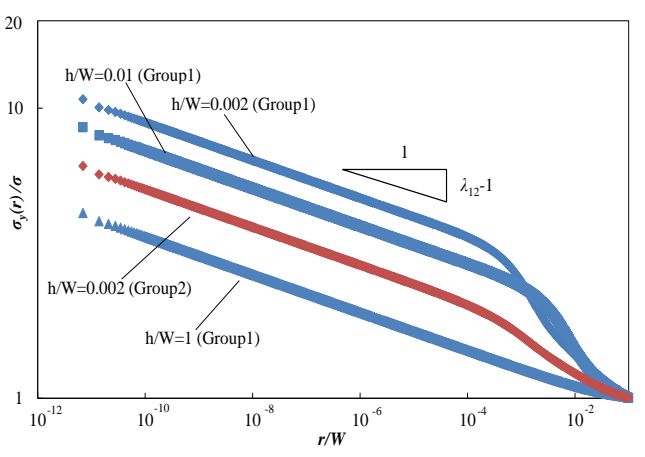

(a) Group 1 and 2

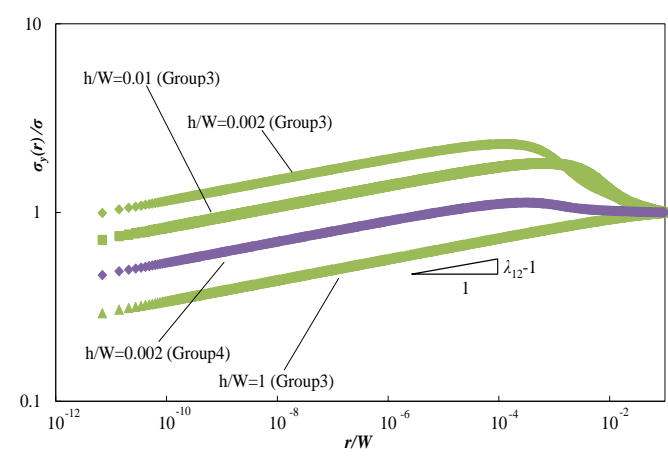

(b) Group 3 and 4

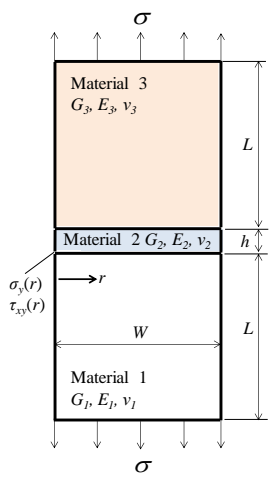

$\sigma$

Fig. 7 Singular stress distribution $\sigma_{y}(r)$ along the interface 12 for various adhesive thickness $h / W$ and material combination. The slopes of singular stress distributions in the double logarithmic plot are determined by Dundurs' parameters $\alpha_{12}$ and $\beta_{12}$ only.

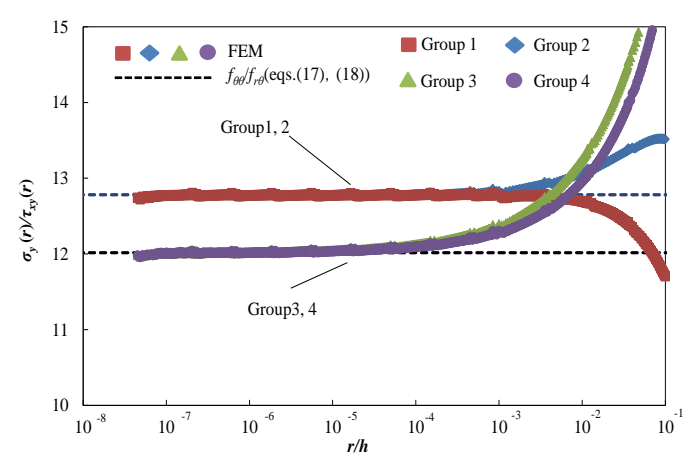

(a) $\sigma_{y}(r) / \tau_{x y}(r)$ along the interface $12(h / W=0.002)$.

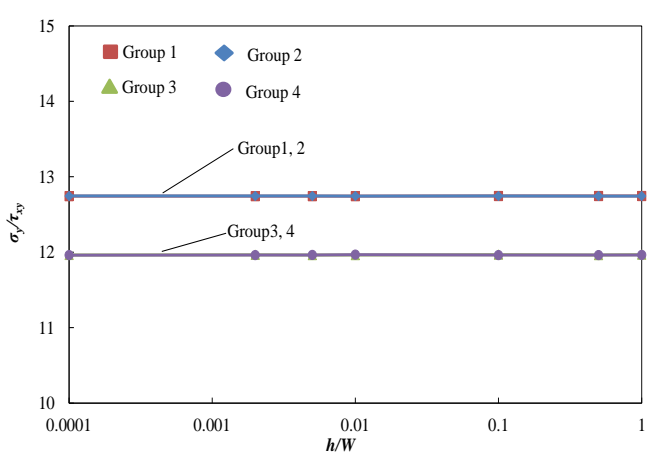

(b) Variation of the ratio $\sigma_{y} / \tau_{x y}$ at the interface edge with $h / W$

Fig.8 Ratio between the singular stress components $\sigma_{y}(r)$ and $\tau_{x y}(r)$ near the interface free edge. The ratio $\sigma_{y} / \tau_{x y}$ near the interface edge is determined by Dundurs' parameters $\alpha_{12}$ and $\beta_{12}$ only, and coincides with the value calculated from eqs. (7) and (8).

\section{$3 \cdot 2$ 微小な界面縁き裂の応力拡大係数と界面端部特異応力場の強さとの関係}

次に，接合界面 12 上に界面縁き裂が生じた場合について検討を行った. FEM で解析したき裂先端の応力值を 用いて, 応力拡大係数 $K_{1}, K_{2}$ を第ゼロ節点法で計算した. 図 9(a)のような切欠きから生じたき裂は, き裂が無い ときの切欠き底のき裂先端位置の応力值を用いて応力拡大係数を近似することが有効である（西谷他，1984）。接 合材（図 9(b)）の微小な界面縁き裂も応力集中部に生じたき裂であるので, き裂先端の応力值を用いて応力拡大 
係数を評価することが可能であると考えられる（図 9 の応力分布はき裂がないときのものである).したがって, 次式のように微小な界面縁き裂の応力拡大係数 $K_{1}, K_{2}$ をき裂先端位置における界面端特異応力值 $\sigma_{y}(a)$ に基づ く係数 $F_{1}, F_{2}$ で定義する. 式(7)を考慮すれば $\left(\sigma_{y}(a)=K_{\sigma} a^{\lambda_{12}-1}\right)$, 応力拡大係数 $K_{1}, K_{2}$ と接合界面端部特異場の 強さ $K_{\sigma}$ との関係が明確になる.

$$
K_{1}+i K_{2}=\left(F_{1}+i F_{2}\right) \sigma_{y}(a) \sqrt{\pi a}(1+2 i \varepsilon)=\left(F_{1}+i F_{2}\right) K_{\sigma} a^{\lambda_{12}-0.5} \sqrt{\pi}(1+2 i \varepsilon)
$$

図 10,11 に式(10)の係数 $F_{1}, F_{2}$ と相対き裂長さ $a / h$ との関係を示す. 解析は，接着層厚さ $h / W$ を固定し，き裂 長さ $a$ を変化させて実施した．図 10,11 より，接着層厚さに対してき裂長さが十分に小さい範囲 $\left(a / h<10^{-2}\right)$

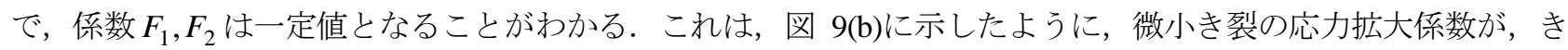
裂の無いときの特異応力場に強く支配されていることを意味する.

以上の結果から, $a / h<10^{-2}$ の場合, 無次元化係数 $F_{1}, F_{2}$ の值は一定值であるため, 応力拡大係数 $K_{1}, K_{2}$ と接

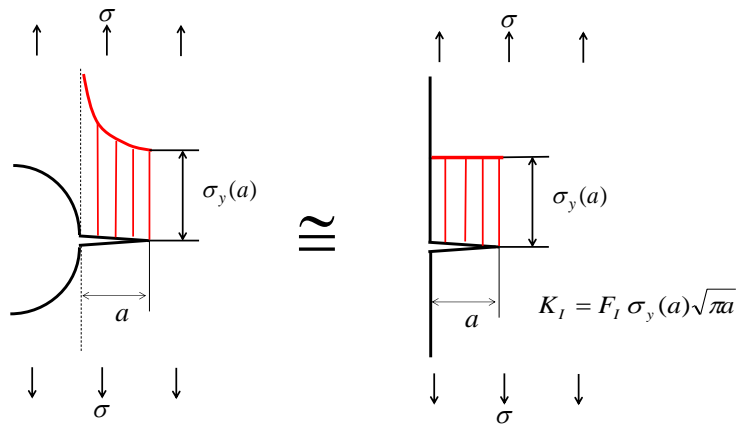

(a) Small crack emanating from notch (Nisitani et al.,1984)

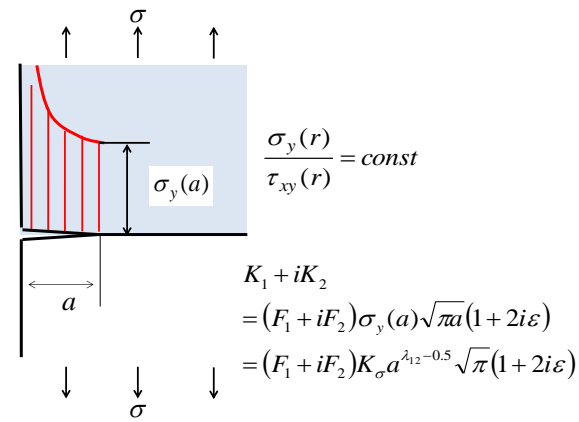

(b) Small edge interface crack

Fig. 9 Normalized stress intensity factor defined by using the stress values $\sigma_{\mathrm{y}}(a)$ at the crack tip position. The red line expresses the stress distribution near the notch or interface edge without the crack.

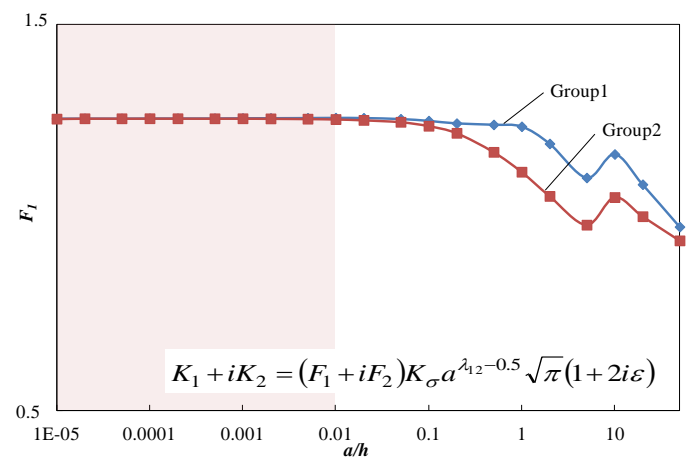

(a) $F_{1}$ vs. $a / h$
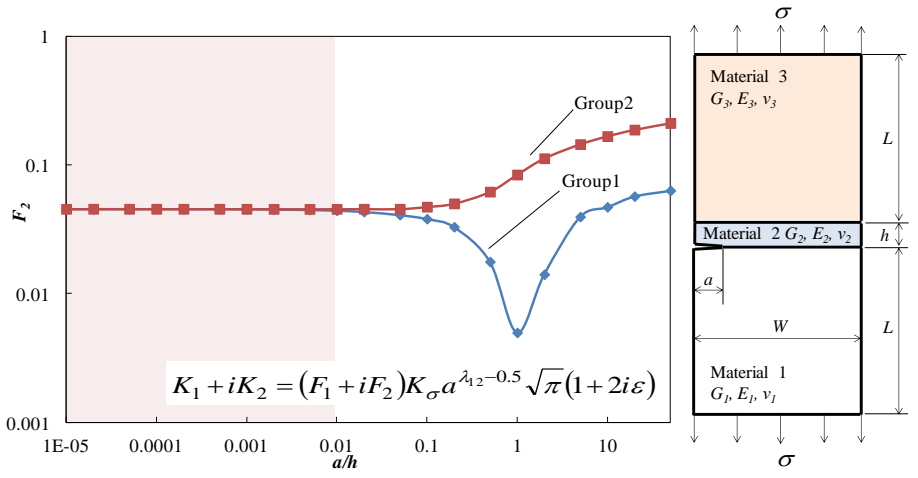

(b) $F_{2}$ vs. $a / h$

Fig. 10 Variation of $F_{1}$ and $F_{2}$ with $a / h$ for a small edge interface crack in butt joint subjected to uniform tension (Group 1,2). FEM analysis is performed by changing the crack length under the fixed $h / W$. The values of $F_{1}$ and $F_{2}$ are almost constant when $a / h<0.01$.

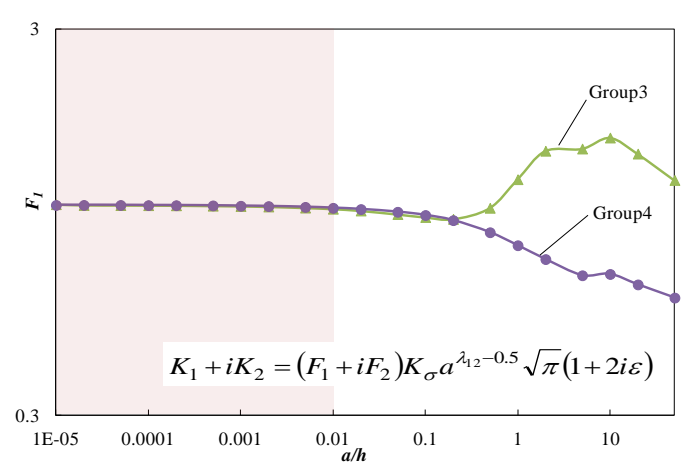

(a) $F_{1}$ vs. $a / h$

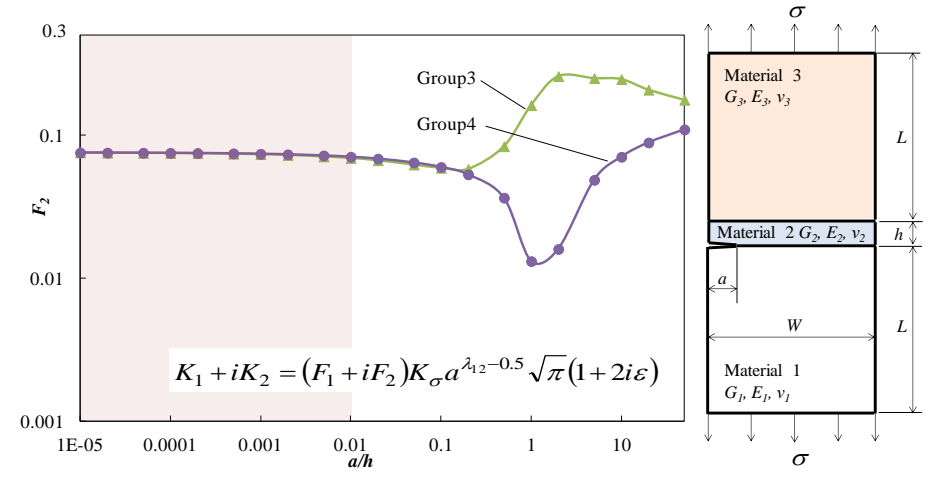

(b) $F_{2}$ vs. $a / h$

Fig. 11 Variation of $F_{l}$ and $F_{2}$ with $a / h$ for a small edge interface crack in butt joint subjected to uniform tension (Group 3, 4). FEM analysis is performed by changing the crack length under the fixed $h / W$. The values of $F_{1}$ and $F_{2}$ are almost constant when $a / h<0.01$. 
合界面端部特異場の強さ $K_{\sigma}$ は等価な関係にあると考えることができる.

\section{$3 \cdot 3$ 無次元化係数 $F_{1}, F_{2}$ に対する接着層厚さおよび接合材長さの影響}

次に, 式(10)で定義した無次元化応力拡大係数 $F_{1}, F_{2}$ の值に対する接着層厚さの影響を検討した. 接着層厚さを $h / W=0.002 \sim 1$ と変化させて解析を行った． $h / W \geq 1$ の場合は接合界面 12 に接着層厚さおよび材料 3 の影響が なくなるため, 図6のような 2 種類の接合材の場合と同じであると考えてよい. 図 12 に $a / W=10^{-6}$ の場合の $F_{1}, F_{2}$ と接着層厚さ $h / W$ の関係を示寸 $\left(a / h<10^{-2}\right.$ となるようにき裂長さを設定した $)$. 図 12 には，それぞれの接着層 厚さ $h / W$ に対する接着接合板の界面端部特異応力場の強さ $K_{\sigma}$ の值を( )内に示している. 図 12 より， $K_{\sigma}$ の值は $h / W$ によって異なるが， $F_{1}, F_{2}$ の值は接着層厚さ $h / W$ の広範囲でほぼ等しいことがわかる. 実用上重要な端部 特異性を有寸る Group1, 2 の組合せではほぼ一定值となっている．このことから， $a / h<10^{-2}$ の範囲で，式(10) で定義した無次元化灾力拡大係数 $F_{1}, F_{2}$ は，接着層厚さに依存せず一定值であるものと考えられる.

また, 接合板の長さ $L$ を $L / W=0.002 \sim 1$ と変化させて, 倸数 $F_{1}, F_{2}$ に対する影響を検討した. 図 13 に $a / W=10^{-6}$ で $h / W=0.002$ の場合 $\left(a / h<10^{-2}\right)$ の $F_{1}, F_{2}$ と接合板の長さ $L / W$ の関係を示す. $L / W=0.002$ の場 合は $L=h=0.002$ であり，同じ厚みの材料を 3 つ重ねている状態なので積層材と考えてよい，それぞれの接合板 の長さ $L / W$ に対する接着接合板の界面端部特異応力場の強さ $K_{\sigma}$ の值を( )内に示す. 図 13 より， $K_{\sigma}$ の值は接 合板の長さ $L$ によって変化するが， $F_{1}, F_{2}$ の值は接合板の長さに関係なくほぼ等しいことがわかる.

以上の結果から, $a / h<10^{-2}$ の場合に一定值として得られる式(10)で定義した無次元化係数 $F_{1}, F_{2}$ は, 材料 1 (下 部被接着材）と材料 2（接着材）の材料組合せに関係する Dundurs 複合パラメータのみに関係する係数であり, 接着層厚さや接合板長さに依存しないと言える.

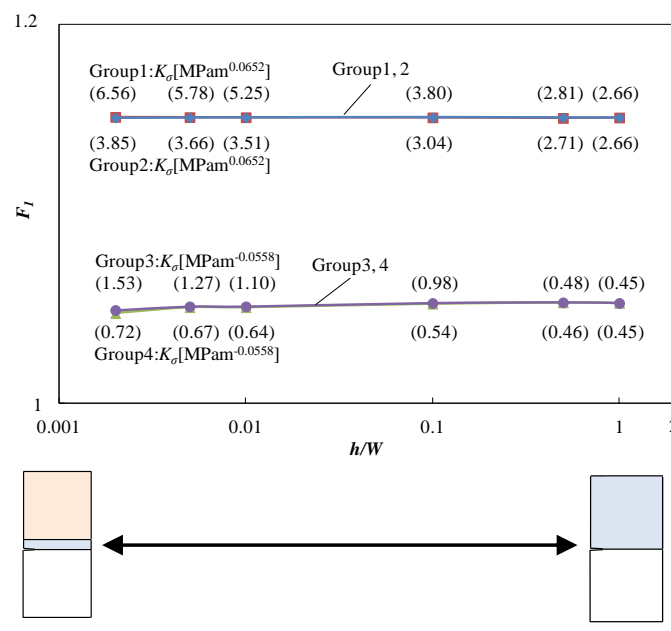

(a) $F_{1}$ vs. $h / W$
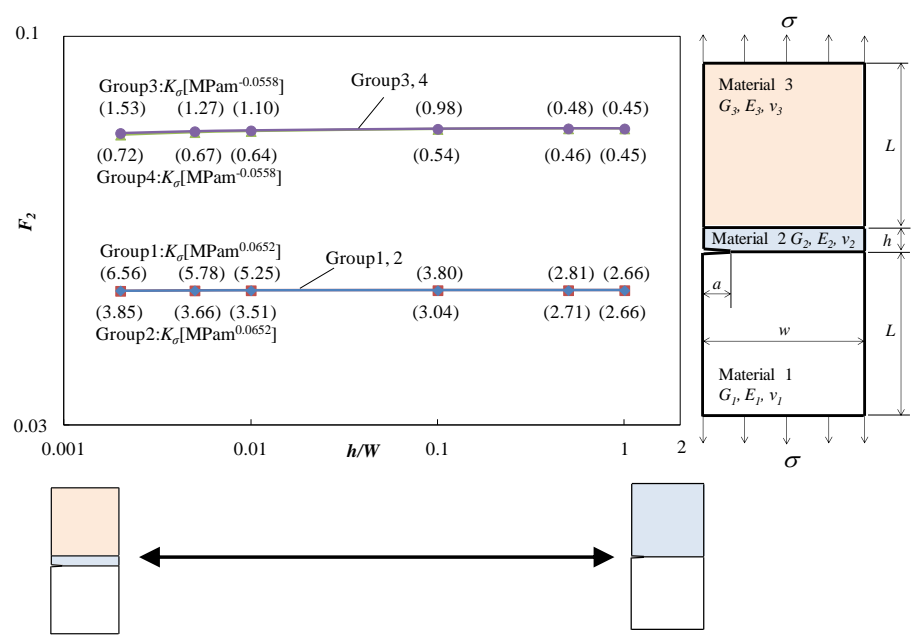

(b) $F_{2}$ vs. $h / W$

Fig.12 Relation between $F_{1}, F_{2}$ and $h / W\left(a / W=10^{-6}, a / h<10^{-2}, \sigma=1\right)$. The values of $F_{1}$ and $F_{2}$ are almost constant irrespective of $h / W$.
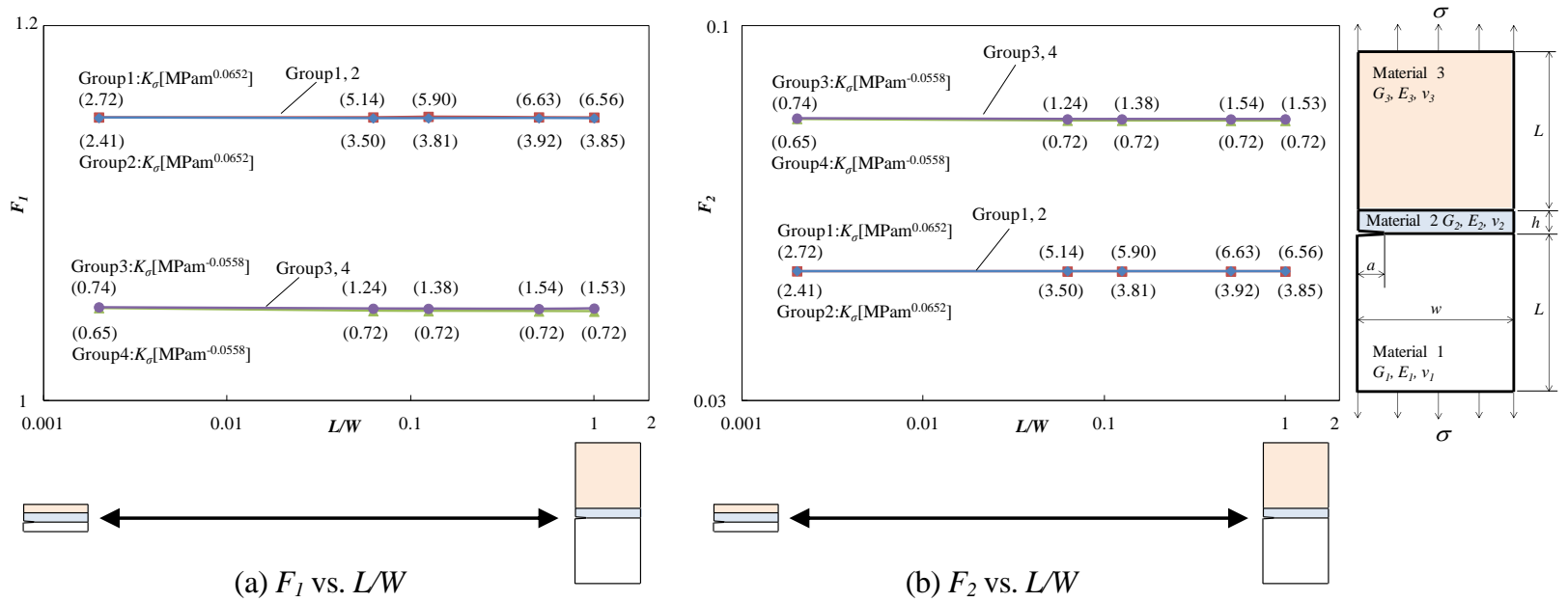

Fig.13 Relation between $F_{1}, F_{2}$ and $\mathrm{L} / W\left(a / W=10^{-6}, h / W=0.002, \sigma=1\right)$. The values of $F_{1}, F_{2}$ are almost constant irrespective of $L / W$. 
図 14 に, Dundurs のパラメータで表される全範囲で解析した係数 $F_{1}, F_{2}$ を示す．表 4,5 には， $\alpha_{12} \geq 0$ の範囲 で求めた係数 $F_{1}, F_{2}$ の数值を示す. 下線で示している数值は, Dundurs パラメータが $\alpha_{12}\left(\alpha_{12}-2 \beta_{12}\right)=0$ (特異性 指数 $\lambda_{12}=1 ）$ の場合である. この係数を用いれば, 式(10)の関係から, 接合界面端部の特異場の強さ $K_{\sigma}$ と微小 界面縁き裂の応力拡大係数 $K_{1}, K_{2}$ を相互に等価なパラメータとして算出可能である.
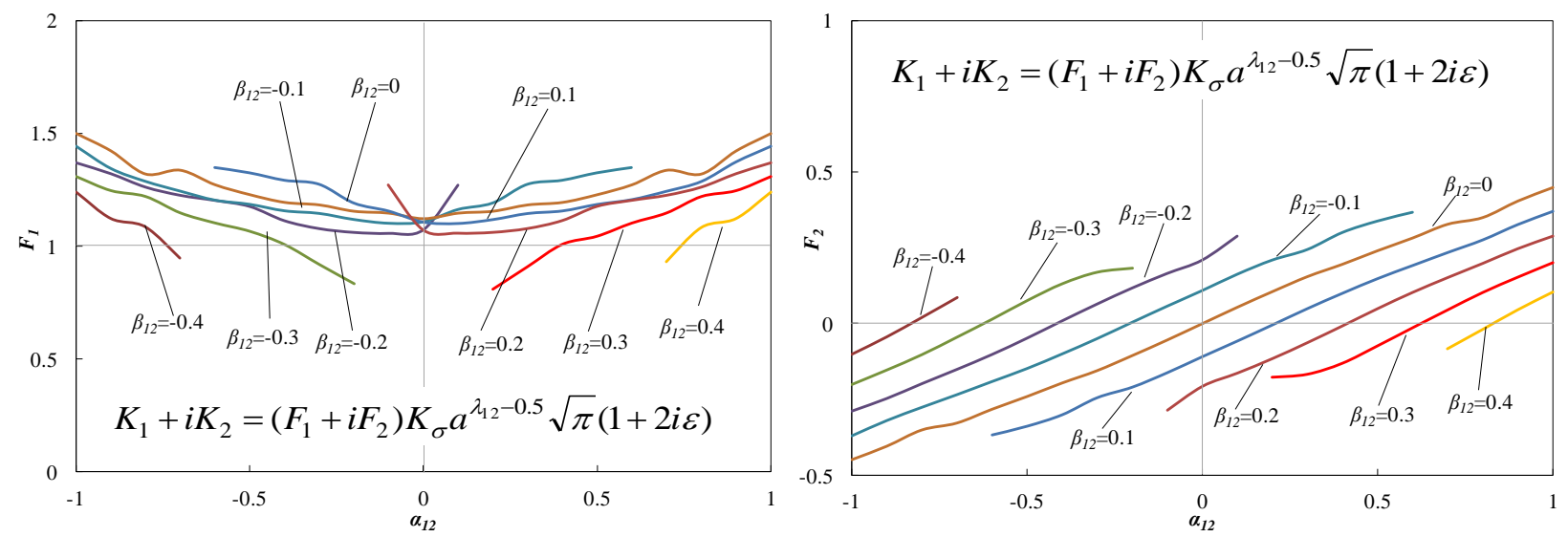

Fig.14 Values of $F_{1}$ and $F_{2}$ as a function of $\alpha_{12}$ and $\beta_{12}$.

Table 4 Values of $F_{1}$ as a function of $\alpha_{12}$ and $\beta_{12}\left[K_{1}+i K_{2}=\left(F_{1}+i F_{2}\right) K_{\sigma} a^{\lambda_{12}-0.5} \sqrt{\pi}(1+2 i \varepsilon)\right]$.

\begin{tabular}{|r|r|r|r|r|r|r|r|}
\hline$\alpha_{12}$ & $\beta_{12}=-0.2$ & $\beta_{12}=-0.1$ & $\beta_{12}=0$ & $\beta_{12}=0.1$ & $\beta_{12}=0.2$ & $\beta_{12}=0.3$ & $\beta_{12}=0.4$ \\
\hline 0 & 1.073 & 1.109 & $\underline{1.121}$ & 1.108 & 1.072 & & \\
0.1 & 1.271 & 1.163 & 1.146 & 1.102 & 1.058 & & \\
0.2 & & 1.192 & 1.154 & $\underline{1.119}$ & 1.061 & 0.808 & \\
0.3 & & 1.274 & 1.182 & 1.146 & 1.078 & 0.909 & \\
0.4 & & 1.292 & 1.194 & 1.157 & $\underline{1.113}$ & 1.008 & \\
0.5 & & 1.325 & 1.228 & 1.186 & 1.176 & 1.044 & \\
0.6 & & 1.348 & 1.272 & 1.207 & 1.203 & $\underline{1.102}$ & \\
0.7 & & & 1.337 & 1.244 & 1.226 & 1.147 & 0.929 \\
0.8 & & & 1.320 & 1.287 & 1.262 & 1.220 & 1.081 \\
0.9 & & & 1.423 & 1.373 & 1.321 & 1.246 & 1.121 \\
1 & & & 1.500 & 1.441 & 1.369 & 1.309 & 1.238 \\
\hline
\end{tabular}

Table 5 Values of $F_{2}$ as a function of $\alpha_{12}$ and $\beta_{12}\left[K_{1}+i K_{2}=\left(F_{1}+i F_{2}\right) K_{\sigma} a^{\lambda_{12}-0.5} \sqrt{\pi}(1+2 i \varepsilon)\right]$.

\begin{tabular}{|r|r|r|r|r|r|r|r|}
\hline$\alpha_{12}$ & $\beta_{12}=-0.2$ & $\beta_{12}=-0.1$ & $\beta_{12}=0$ & $\beta_{12}=0.1$ & $\beta_{12}=0.2$ & $\beta_{12}=0.3$ & $\beta_{12}=0.4$ \\
\hline 0 & 0.209 & 0.109 & $\underline{0.000}$ & -0.109 & -0.208 & & \\
0.1 & 0.288 & 0.163 & 0.054 & -0.057 & -0.165 & & \\
0.2 & & 0.210 & 0.105 & $\underline{-0.004}$ & -0.117 & -0.177 & \\
0.3 & & 0.245 & 0.155 & 0.050 & -0.064 & -0.167 & \\
0.4 & & 0.301 & 0.196 & 0.101 & $\underline{-0.009}$ & -0.131 & \\
0.5 & & 0.339 & 0.240 & 0.149 & 0.048 & -0.073 & \\
0.6 & & 0.368 & 0.282 & 0.192 & 0.102 & $\underline{-0.014}$ & \\
0.7 & & & 0.327 & 0.235 & 0.151 & 0.046 & -0.083 \\
0.8 & & & 0.349 & 0.277 & 0.198 & 0.103 & $\underline{-0.019}$ \\
0.9 & & & 0.404 & 0.328 & 0.246 & 0.154 & 0.045 \\
1 & & & 0.448 & 0.371 & 0.288 & 0.202 & 0.103 \\
\hline
\end{tabular}




\section{4. 結 言}

本研究では, 引張りが作用する上下の材料が異なる接着接合板の界面 12 上の界面端部特異応力場の強さ $K_{\sigma}$ と 界面縁き裂の応力拡大係数 $K_{1}, K_{2}$ に及ぼす材料組合せや接着層厚さの影響について FEM 解析を行い, 界面端部 特異応力場と応力拡大係数の関係について検討した．得られた知見をまとめると次のようになる.

(1) 界面 12 上の接合端部近傍の応力について検討した結果（図 7，8), 界面 12 上の接合界面端特異応力場は, 材料 3 (上部被接着材) および接着層厚さに関係なく, 応力特異性指数 $1-\lambda_{12}$ および応力成分の比 $\sigma_{y} / \tau_{x y}$ は 一定であり，材料 1（下部被接着材）と2（接着材）の組合せの夕によって決まることがわかった.

(2) 微小な界面縁き裂の応力拡大係数 $K_{1}, K_{2}$ をき裂先端位置における界面端特異応力 $\sigma_{y}(a)$ に基づく係数 $F_{1}, F_{2}$ で次のように定義した。

$$
K_{1}+i K_{2}=\left(F_{1}+i F_{2}\right) K_{\sigma} a^{\lambda_{12}-0.5} \sqrt{\pi}(1+2 i \varepsilon)
$$

き裂長さと接着層厚さの比 $a / h<10^{-2}$ の場合，無次元化係数 $F_{1}, F_{2}$ の值は常に一定であり，材料 1 (下部被 接着材）と材料 2（接着材）の材料組合せに関係する Dundurs パラメータのみに依存する（図 10，11）.

(3) 接着層厚さ $h$ と板の長さ $L$ の影響についても検討した結果, 接着層厚さや板の長さが広範囲に変化しても無 次元化係数 $F_{1}, F_{2}$ の值は常に一定である（図 12,13$)$.

（4）本研究の解析結果から，接着接合板の微小な界面縁き裂の応力拡大係数と界面端部特異応力場の強さは等価 なパラメータであり，式(10)より互いに変換可能であることがわかった，そのため，どちらのパラメータを 用いても本質的に等価な強度評価を行うことができる.

\section{文献}

Afendi, M., Abdul, M.S., Daud, R., Abdul, A. and Teramoto, T., Strength prediction and reliability of brittle epoxy adhesively bonded dissimilar joint, International Journal of Adhesion and Adhesives, Vol.45 (2013), pp.21-31.

Akisanya, A.R. and Meng, C.S., Initiation of fracture at the interface corner of bi-material joints, Journal of the Mechanics and Physics of Solids, Vol. 51 (2003), pp.27-46.

Bogy, D.B., Edge-bonded dissimilar orthogonal elastic wedges under normal and shear loading, Transaction of the ASME, Journal of Applied Mechanics, Vol.35 (1965), pp.460-466.

陳玳珩, 西谷弘信, 接着異材角部の特異応力場について, 日本機械学会論文集 A 編, Vol.57, No.542（1991）, pp.2509-2515.

陳玳珩, 西谷弘信, 板状接合試験片における特異応力場の強さ, 日本機械学会論文集 A 編, Vol.59, No.567 (1993), pp.2682-2686.

井岡誠司，松田崇，久保司郎，異種接合材料の界面端微小き裂の応力拡大係数と自由縁応力特異性の関係に関す る数值的および理論的検討, 材料, Vol.51, No.12 (2002), pp.1373-1379.

西谷弘信, 陳玳珩, 石田誠, だ円孔縁の発生した各種縁き裂の $\mathrm{K}_{\mathrm{I}}, \mathrm{K}_{\mathrm{II}}$ の近似計算法, 日本機械学会論文集 $\mathrm{A}$ 編, Vol.50, No.451 (1984), pp.341-350.

野田尚昭，蘭欣，道中健吾，張玉，小田和広，任意の材料組合せを考慮した縁界面き裂を有する接合半無限板の 応力拡大係数, 日本機械学会論文集 A 編, Vol.76, No.770 (2010), pp.1270-1227.

Noda, N.-A., Miyazaki, T., Li, R., Uchikoba, T., Sano, Y. and Takase, Y., Debonding strength evaluation in terms of the intensity of singular stress at the interface corner with and without fictitious crack, International Journal of Adhesion and Adhesives, Vol. 61 (2015), pp. 46-64.

野田尚昭, 宮㠃達二郎，内木場卓巳，李戎，佐野義一，高瀬康，接着接合板における特異応力の強さを用いた接 着強度の簡便な評価法について, エレクトロニクス実装学会誌, Vol.17, No.2 (2014), pp.132-142.

小田和広，神杉一吉，野田尚昭，比例法による界面き裂の応力拡大係数解析，日本機械学会論文集 A 編，Vol.75, No.752 (2009), pp.476-482.

小田和広, 野田尚昭, 応力場の等価性に基づく界面き裂問題の高度解析法，日本機械学会論文集 A 編，Vol.78, No.789 (2012), pp.642-645.

小田和広, 高畑洋介, 野田尚昭, 堤紀子, 界面縁き裂の応力拡大係数に及ぼす接着層厚さの影響, 日本機械学会 論文集，Vol.81, No.829（2015），DOI:10.1299/transjsme.15-00145.

Suzuki, Y., Adhesive tensile strengths of scarf and butt joints of steel plates (Relation between adhesive layer thicknesses and 
adhesive strengths of joints), JSME International Journal, Vol. 30, No. 265 (1987), pp. 1042-1051.

張玉，野田尚昭，高石謙太郎，蘭欣，接着接合板における接着層厚さが特異応力場の強さに与える影響，日本機 械学会論文集 A 編，Vol.77, No.774 (2011a)，pp.360-372.

張玉，高石謙太郎，野田尚昭，蘭欣，接着接合板における接着層厚さが特異応力場の強さに与える影響（面内曲 げと引張りの比較)，日本機械学会論文集 A 編，Vol.77, No.784 (2011b)，pp.2076-2086.

\section{References}

Afendi, M., Abdul, M.S., Daud, R., Abdul, A. and Teramoto, T., Strength prediction and reliability of brittle epoxy adhesively bonded dissimilar joint, International Journal of Adhesion and Adhesives, Vol.45 (2013), pp.21-31.

Akisanya, A.R. and Meng, C.S., Initiation of fracture at the interface corner of bi-material joints, Journal of the Mechanics and Physics of Solids, Vol. 51 (2003), pp.27-46.

Bogy, D.B., Edge-bonded dissimilar orthogonal elastic wedges under normal and shear loading, Transaction of the ASME, Journal of Applied Mechanics, Vol.35 (1965), pp.460-466.

Chen, D. and Nisitani, H., Singular stress field near a corner of jointed dissimilar materials, Transactions of the Japan Society of Mechanical Engineers, Series A, Vol. 57, No. 542 (1991), pp. 2509-2515 (in Japanese).

Chen, D. and Nisitani, H., Intensity of singular stress field near the interface edge point of a bonded strip, Transactions of the Japan Society of Mechanical Engineers, Series A, Vol. 59, No. 567 (1993), pp. 2682-2686 (in Japanese).

Ioka, S., Matsuda, T. and Kubo, S., A numerical and theoretical study on relationship between stress intensity factor of a small interface crack on interface and free-edge stress singularity of bonded dissimilar materials, Journal of the Society of Materials Science, Japan, Vol. 51, No. 12 (2002), pp. 1373-1379 (in Japanese).

Nisitani, H., Chen, D. and Isida, M., An approximate method for calculating $\mathrm{K}_{\mathrm{I}}$ and $\mathrm{K}_{\mathrm{II}}$ of various edge cracks emanating from the apex of an elliptic hole, Transactions of the Japan Society of Mechanical Engineers, Series A, Vol. 50, No. 451 (1984), pp. 341-350 (in Japanese).

Noda, N.-A., Lan, X., Michinaka, K., Zhang, Y. and Oda, K., Stress intensity factor of an edge interface crack in a bonded semi-infinite plate, Transactions of the Japan Society of Mechanical Engineers, Series A, Vol. 76, No. 770 (2010), pp. 1270-1277 (in Japanese).

Noda, N.-A., Miyazaki, T., Li, R., Uchikoba, T., Sano, Y. and Takase, Y., Debonding strength evaluation in terms of the intensity of singular stress at the interface corner with and without fictitious crack, International Journal of Adhesion and Adhesives, Vol. 61 (2015), pp. 46-64.

Noda, N.-A., Miyazaki, T., Uchikoba, T., Li, R., Sano, Y. and Takase, Y., Convenient debonding strength evaluation based on the intensity of singular stress for adhesive joints, Journal of The Japan Institute of Electronics Packaging, Vol. 17, No.2 (2014), pp. 132-142 (in Japanese).

Oda, K., Kamisugi, K. and Noda, N.-A., Analysis of stress intensity factor for interface cracks based on proportional method, Transactions of the Japan Society of Mechanical Engineers, Series A, Vol. 75, No. 752 (2009), pp. 476-482 (in Japanese).

Oda, K., and Noda, N.-A., Finite element analysis of interface crack problem based on the equivalence of stress field, Transactions of the Japan Society of Mechanical Engineers, Series A, Vol. 78, No. 789 (2012), pp. 642-645 (in Japanese).

Oda, K., Takahata, Y., Noda, N.-A. and Tsutsumi, N., Effect of adhesive thickness on stress intensity factor for edge interface crack in adhesively-bonded joint, Transactions of the JSME (in Japanese), Vol.81, No.829 (2015), DOI:10.1299/transjsme.15-00145.

Suzuki, Y., Adhesive tensile strengths of scarf and butt joints of steel plates (Relation between adhesive layer thicknesses and adhesive strengths of joints), JSME International Journal, Vol. 30, No. 265 (1987), pp. 1042-1051.

Zhang, Y., Noda, N.-A., Takaishi, K. and Lan, X., Effect of adhesive thickness on the intensity of singular strength for the adhesive joint, Transactions of the Japan Society of Mechanical Engineers, Series A, Vol. 77, No. 774 (2011a), pp. 360-372 (in Japanese).

Zhang, Y., Takaishi, K., Noda, N.-A. and Lan, X., Effect of adhesive thickness on the intensity of singular strength for the adhesive joint (Comparison between bending and tension), Transactions of the Japan Society of Mechanical Engineers, Series A, Vol. 77, No. 784 (2011b), pp. 2076-2086 (in Japanese). 